\title{
Treatment of Wastewater from Rubber Industry Using Calcium Carbide Residue Adsorbent and Hybrid Membrane UF - RO
}

\author{
Susi Susanti ${ }^{1}$, Subriyer Nasir ${ }^{2 *}$, Hermansyah $^{3}$, Agung Mataram ${ }^{4}$ \\ ${ }^{1}$ Graduate Program Student, Chemical Engineering Magister Program, Universitas Sriwijaya, Indonesia \\ ${ }^{2}$ Department of Chemical Engineering, Faculty of Engineering, Universitas Sriwijaya, Indonesia \\ ${ }^{3}$ Department of Chemistry, Faculty of Mathematics and Natural Sciences, Universitas Sriwijaya, Indonesia \\ ${ }^{4}$ Department of Mechanical Engineering, Faculty of Engineering, Universitas Sriwijaya, Indonesia \\ "Corresponding Author: subriyer@unsri.ac.id
}

\begin{tabular}{|c|c|c|c|}
\hline & & & \\
\hline 14 February 2019 & 26 April 2019 & 27 April 2019 & 27 April 2019 \\
\hline
\end{tabular}

\begin{abstract}
Hybrid UF - RO membrane technology is one of the new technologies of separation wastewater from the rubber industry to decrease turbidity and heavy metal contents such as iron and zinc. This technology is being used to replace the conventional installation process of wastewater treatment. Processing wastewater treatment from the rubber industry with the hybrid UF - RO membrane can produce permeate with quality standards, making it possible to be recycled as domestic water for water process in the industry regarding to Government Regulation number 82 of 2001. The technology of wastewater treatment from the rubber industry in this experiment involved the pre-treatment stage, using sand filter and adsorption using calcium carbide residue. The operating variables by flow rate into the UF and RO were 7 and 14 L.Min ${ }^{-1}$ and operation time were 15 to 90 minutes. The results of this study showed that the percentage reduced were $62.73 \%$ for turbidity, $83.28 \%$ for iron and $88.89 \%$ for zinc, respectively. Finally, it can be concluded that calcium carbide residue was potential to reduced turbidity and heavy metals such as iron and zinc from rubber industry wastewater content.
\end{abstract}

Keywords: Calcium Carbide Residue, Hybrid Membrane UF - RO, Rubber Industry, Sand Filter

Abstrak (Indonesian): Teknologi hibrid membran UF - RO adalah salah satu teknologi terbaru untuk separasi air limbah dari industri karet guna menurunkan nilai kekeruhan dan mengurangi kandungan logam berat seperti besi dan seng. Di sektor pengolahan, untuk pengolahan air limbah dari industri karet, hibrid membran UF - RO dapat bekerja untuk mengolah limbah dengan kualitas lebih baik, sehingga memungkinkan untuk didaur ulang sebagai air domestik guna sebagai air proses mengacu kepada Standar Baku Mutu Air Limbah menurut Peraturan Pemerintah No.82 Tahun 2001. Teknologi pengolahan air limbah industri karet mencakup tahap pra-pengolahan, menggunakan saringan pasir dan adsorpsi menggunakan residu kalsium karbida. Variabel operasi pada laju alir ke dalam membrane UF dan RO adalah 7 dan 14 L.Menit $^{-1}$ dan waktu operasi berkisar antara 15 sampai dengan 90 menit. Hasil penelitian ini menunjukkan bahwa persentase penurunan untuk kekeruhan adalah sebesar $62.73 \%$, untuk persentase penurunan kadar besi sebesar $83.28 \%$, dan persentase penurunan kadar seng sebesar $88.89 \%$, secara berurutan. Kesimpulan dari penelitian ini, bahwa residu kalsium karbida sangat potensial untuk mereduksi kekeruhan dan kadar kandungan logam besi dan seng dari air limbah industri karet.

Kata kunci: Residu Kalsium Karbida, Hybrid Membrane UF - RO, Industri Karet, Saringan Pasir

\section{Introduction}

Rubber (Hevea brasiliensis) are found in the Southeast Asia, where most of the world's rubber is produced, around 70 percent of global production comes from Thailand, Indonesia and Malaysia [1]. As the second largest rubber producer, Indonesia supplies a substantial amount of rubber to the global market. Moreoever, some changes in land use occured in the middle 1980s and large areas of the rubber field were converted for industrial, commercial and residential uses [2]. Rubber processing industries consume a large volume of water and chemicals. A considerable amount of wastewater is generated along with effluent which is extremely toxic and has a strong colour, a large amount of suspended solids, highly fluctuating $\mathrm{pH}$, high temperature, $\mathrm{COD}$ and BOD [3]. Because of these characteristics, treatment of rubber wastewater is an essential requirement before it is disposed of in the natural water system [4].

Rubber industry in general, was using a conventional wastewater treatment, which consume more energy and electricity than using hybrid membrane treatment. Conventional treatment is not sufficient to achieve the water quality requirements need for recycling wastewater and that is why a combination of two or more advanced 
treatment processes is usually required [5].

Conventional wastewater treatment is being replaced by the technology of hybrid membrane UF-RO, which is better for environment. Because, we can avoid to used chemicals for treat the wastewater so it can be recycled again and disposed into the environment when it meet with quality standards [6]. The first stage of this system is pre-treatment, which involves sand filter (active carbon and silica) and adsorption using a calcium carbide residue as an adsorbent. As a solid waste from the welding process, it can be used again as a sustainable alternative to traditional stabilizers for soil, chemical products as a partial replacement of cement in concrete, and as a treatment environmental pollution to decreasing the heavy metals content [7].

In a previous study, the feasibility of using an UF/RO membrane treatment to reuse oily wastewater was investigated. The results showed that a Transmembrane pressure (TMP) of 3 bar, a Crossflow velocity (CFV) of 1 $\mathrm{m} / \mathrm{s}$, a temperature of $40^{\circ} \mathrm{C}$ and a $\mathrm{pH}$ of 9 are the best operating parameters. The application of a hybrid UF/RO system to convert excessive amounts of API unit of Tehran refinery wastewater into fresh recyclable water showed to be feasible. In order to recycle the refinery oily wastewater effluent as cooling water makeup, UF is considered to be good pre-treatment for RO process, which has to remove further dissolved inorganic and organic compounds, in order to achieve the requirement for recycling. Application of RO post-treatment, allows RO permeate back into cooling tower. The removal of COD increased up to $98 \%$ and TDS increased up to $95 \%$ after UF/RO treatment. RO treatment is used to recycle wastewater so it can be used for industrial water (make-up cooling tower) [8].

The recent study also discussed the comparison of silica adsorbent, activated carbon and zeolite in reducing ammonia, iron, COD, turbidity and phosphate pollutants. In this study, the effect of discharge on the pollutant removal was investigated. In general, decreasing discharge raises the removal yield of pollutants. The results showed that $83 \%$ decrease of discharge rate can increase the ammonium removal about 30\% (in each adsorbent). Also, the discharge has so much effect that the decrease of discharge can raise iron removal from 0 to $27 \%$ using zeolite. It should be noted that the effect of the discharge is negligible when the removal yield is high and the adsorbent can efficiently remove the pollutants [9].

Research on the adsorptivity of diesel oil desulfurization using Alkynyl Carbon Material (ACM) formed from calcium carbide and polyhalohydrocarbon was studied by Wenfeng (2017). Overall, ACM-6 represents the best adsorption desulfurization (ADS) adsorbent among all mesoporous carbon materials, and can affect the original oil after further modification [10]. The new recently study by Yang (2018), membrane coated with cobalt-doped silica (CoSi-35 membrane) is use to reduce ammonia and total nitrogen levels.
However, the weakness of this study is that the flux of the membrane decreases with increasing concentration of cobalt which shows a rejection of ammonia and total nitrogen up to $99 \%$ at high temperatures of $65^{\circ} \mathrm{C}$ and basic acidity $(\mathrm{pH}>10)$ and removal of total Nitrogen and Cobalt mineral rejection are $97 \%$ and $99 \%$, respectively [11].

In the study, we used sand filter as pre-treatment and calcium carbide residue (adsorbent), followed by the technology of hybrid membrane, using ultrafiltration and reverse osmosis for a wastewater treatment of rubber industry with varying flow rate and operation time.

\section{Materials and Methods}

This research was conducted at Laboratory Separation and Purification, Universitas Sriwijaya, Inderalaya, South Sumatera.

\subsection{Materials}

Wastewater of rubber industry sample comes from rubber processing industry at Gandus, Palembang City, South Sumatera, Indonesia. The sand filter column contains $15 \mathrm{~kg}$ of activated carbon and $15 \mathrm{~kg}$ of silica placed in the sand filter column. The adsorbent column contain $25 \mathrm{~kg}$ of calcium carbide residue as a dried adsorbent which activated physically using an oven with the temperature of $120^{\circ} \mathrm{C}$ and grinded with particles size of $250 \mu \mathrm{m}$ (60 mesh) inside the adsorption column, the main equipment to treat the feed adsorbent product, using technology hybrid membrane UF- RO. Spectrophotometer type UV-200RS, and turbidity meter thermo scientific merk EUTECH TN-100 was used to determine the results of the parameters.

\subsection{Methods}

Preliminary the laboratory analyzes of turbidity was conducted using Turbidity meter (thermo scientific merk EUTECH TN-100). Spectrophotometer type UV-200RS was used to analyze iron and zinc regarding with experimental reference for Iron content is regulated at Indonesian National Standard No. 06-6989.4-2004. While the Zinc content experimental reference is regulated at Indonesian National Standard No. 6989.7-2009. Wastewater sample was accomodated into the Tank with capacity of $1200 \mathrm{~L}$ and was pumped into sand filter column. After that we used adsorption column using calcium carbide residue for the next step. For the final stage we used hybrid membrane UF - RO with flow rate variations 7 and $14 \mathrm{~L}_{\mathrm{min}} \mathrm{m}^{-1}$ and operation time 15, 30, 45, 60 and 90 minutes. Turbidity and heavy metal contents such as iron and zinc was analyzed every each stage from the process.

\subsubsection{Procedures}

Schematic of the experiment was shown at Figure 1. Initial sample was carried out in the form of liquid waste from the rubber industry, were analyzed for turbidity and heavy metals content such as iron and zinc. 


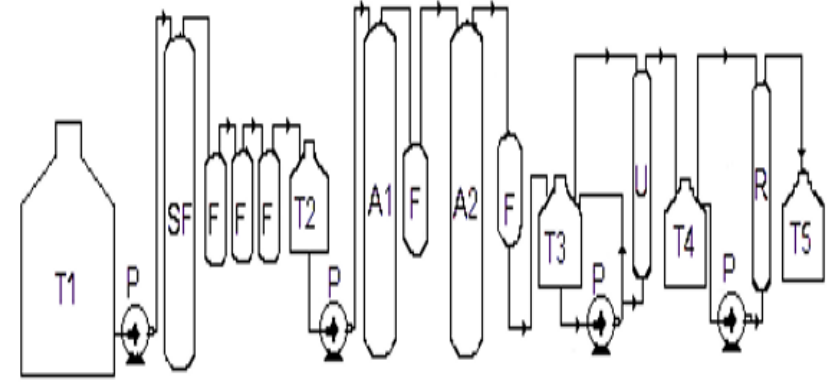

Figure 1. Wastewater Treatment of Rubber Industry Experimental Set-Up

$(\mathrm{T} 1=$ Feed Tank, $\mathrm{T} 2=$ Product Tank of Sand Filter, $\mathrm{T} 3$ $=$ Feed Tank of UF, T4 = UF Tank, T5 $=$ Product Tank of RO, SF $=$ Sand Filter Column, $\mathrm{A}=$ Adsorbent Column, $\mathrm{U}$ $=$ Membran UF, $\mathrm{R}=$ Membran RO, $\mathrm{F}=$ Spons Filter, $\mathrm{P}$ = Pump)

Samples was pumped to the sand filter column and calcium carbide residue column, feed flow rate constant 5 L. $\min ^{-1}$ and then was accommodated in the membrane ultrafiltration tank. Then samples were taken for every 15 , 30, 45, 60 and 90 minutes with a glass beaker and samples were analyzed for parameter (turbidity, iron and zinc).

Samples was pumped to membrane ultrafiltration with flow rate $7 \mathrm{~L} \cdot \mathrm{min}^{-1}$. Followed by $14 \mathrm{~L} \cdot \mathrm{min}^{-1}$ for the next sample. Samples were taken for every 15, 30, 45, 60 and 90 minutes with a glass beaker and samples were analyzed for parameter content (turbidity, iron and zinc). Samples were pumped into the next tank. After the tank is full, the sample was pumped to reverse osmosis membrane with flow rate 7 L.min ${ }^{-1}$. Followed by 14 L. $\min ^{-1}$ for the next sample. Then take samples for every $15,30,45,60$ and 90 minutes for each flow rate with a glass beaker and samples were analyzed for parameter content such as turbidity, iron and zinc. Then the sample was collected in the final reservoir tank.

\subsection{Data Analysis}

The samples were taken at flow rate 7 and $14 \mathrm{~L} \cdot \mathrm{min}^{-1}$ with variation in operating time $15,30,45,60$ and 90 minutes for analyze turbidity and heavy metal contents such as iron and zinc using Turbidity meter and Spectrophotometer.

\section{Results and Discussion}

The initial sample about turbidity value and concentration of Iron and Zinc from the rubber industry is shown at Table 1.

Table 1. Initial Sample of Wastewater from The Rubber Industry

\begin{tabular}{lcc}
\hline \multicolumn{1}{c}{ Parameter } & Unit & Value \\
\hline Turbidity & NTU & 268 \\
Iron & mg/L & 0.317 \\
Zinc & mg/L & 0.027 \\
\hline
\end{tabular}

\subsection{The effect of flow rate and operation time on} decreasing turbidity

The pre-treatment process (sand filter), adsorption process (calcium carbide residue) and hybrid membrane UF - RO with flow rate 7 and $14 \mathrm{~L} \cdot \mathrm{min}^{-1}$ and operating time (15, 30, 45, 60 and 90 minutes). If the operating time is longer, then the contact time for the wastewater to eliminated the pollutant will be longer [12]. Turbidity inorganic materials, or organic matter such as algae, plankton and decaying material. In addition to these suspended solids, turbidity can also include colored dissolved organic matter (CDOM), fluorescent dissolved organic matter (FDOM) and other dyes [13].

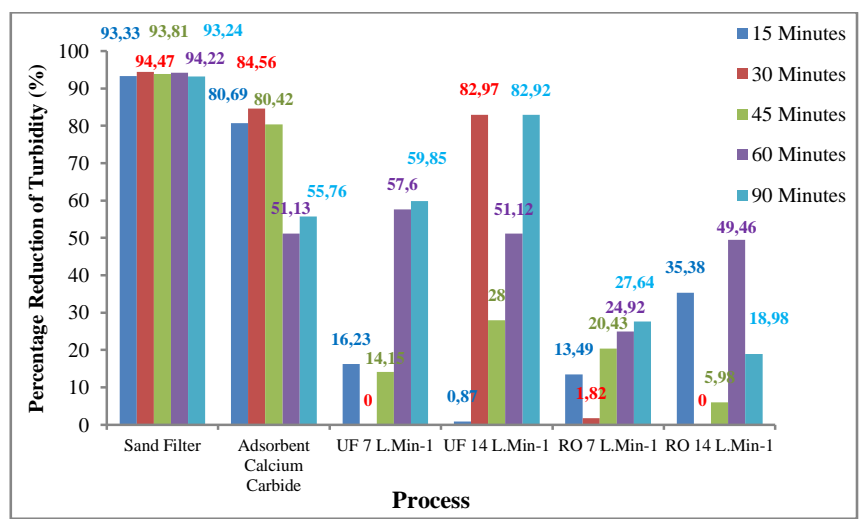

Figure 2. The effect of flow rate and operation time on decreasing Turbidity

The results of the initial analysis for turbidity in rubber wastewater were 268 NTU. The effect of flow rate and operation time on decreasing turbidity is shown in Figure 2, that the use of sand filter can reduce turbidity ranging from $93-94 \%$ at an operating time of 15 to 90 minutes. Then the next stage, an adsorption column with calcium carbide residue showed the percentage reduction of turbidity ranging from $80-84 \%$ and then decrease to 51 $56 \%$. There is no large difference in turbidity removal percentage with variation time in the sand filter and adsorbent calcium carbide residue column. The pretreatment process aims to relieve the performance of hybrid membrane ultrafiltration and reverse osmosis and prevent biofouling on the membrane.

Afterward, the variation in the feed flow rate and operating time in hybrid membrane UF - RO shows a fluctuating and unstable result with the percentage reduction of turbidity. In the membrane ultrafiltration with a feed of flow rate $7 \mathrm{~L} \cdot \mathrm{min}^{-1}$ at an operating time of 15 to 90 minutes, showed the percentage reduction of turbidity ranging from $14-16 \%$ and then increase up to $57-60 \%$. At the feed of flow rate of $14 \mathrm{~L} \cdot \mathrm{min}^{-1}$ at an operating time 15 minute showed the percentage reduction of turbidity is $0.87 \%$ which UF membrane in unstable condition, then at 90 minutes increased up to $83 \%$.

The results showed that the optimum condition in the membrane ultrafiltration is a feed of flow rate $7 \mathrm{~L} \cdot \mathrm{min}^{-1}$, 
which at a lower feed of flow rate the rate of reduction obtained was higher, while the permeate drags all the solids in the feed solution to the membrane surface resulting in solute adsorption and deposition on the membrane surface and inside the pores. The separation mechanism is not a simple sieve mechanism where the particles with sizes smaller than the pore size flow freely through the pore while the larger particles are rejected [14]. The reverse osmosis membrane with a feed flow rate of $7 \mathrm{~L} \cdot \mathrm{min}^{-1}$ at an operating time of 15 to 90 minutes, showed the percentage reduction of turbidity ranging from $13-28 \%$. At the feed of flow rate of $14 \mathrm{~L} \cdot \mathrm{min}^{-1}$ at an operating time of 15 minute showed the percentage reduction of turbidity is $35 \%$ and increase up to $49.5 \%$ at 60 minutes. Then at 90 minutes decrease to $19 \%$. The results showed the best percentage reduction of turbidity in the membrane reverse osmosis is a feed of flow rate 7 L. $\min ^{-1}$.

\subsection{The effect of flow rate and operating time on decreasing Iron concentration}

The results of the initial iron analysis in rubber wastewater were $0.317 \mathrm{mg} \cdot \mathrm{L}^{-1}$. The effect of flow rate and operation time on decreasing Iron concentration is shown in Figure 3.

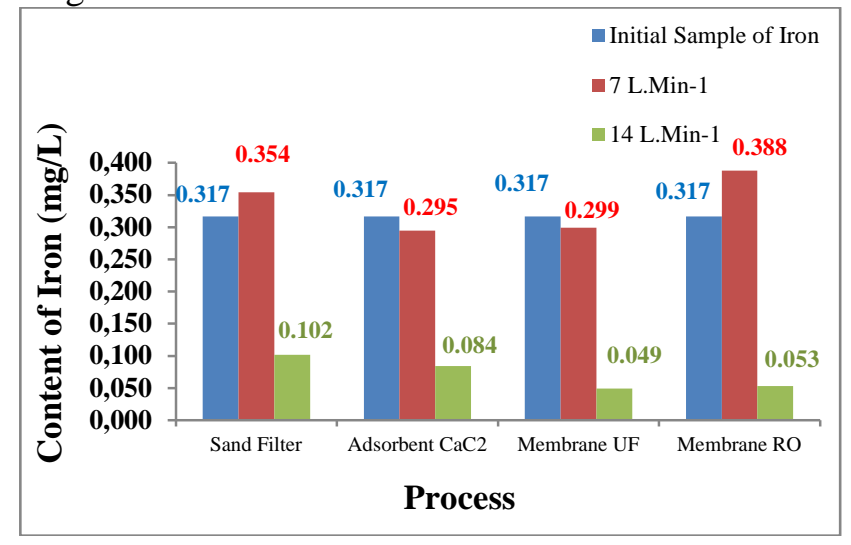

Figure 3. The effect of flow rate and operation time on decreasing Iron concentration

Figure 3 shows that the use of the sand filter column showed the lowest iron concentration is $0.102 \mathrm{mg} \cdot \mathrm{L}^{-1}$. Continued with the use of calcium carbide residue adsorbent column showed the lowest iron concentration is $0.084 \mathrm{mg} . \mathrm{L}^{-1}$. This indicated that the addiction of the adsorption process using calcium carbide residue resulted in greater iron removal. Afterward, at variation flow rate 7 and $14 \mathrm{~L} \cdot \mathrm{min}^{-1}$ in hybrid membrane UF - RO, shown that the feed flow rate of $14 \mathrm{~L} \cdot \mathrm{min}^{-1}$ is the optimum condition on decreasing iron concentration. The membrane ultrafiltration with a feed flow rate of $14 \mathrm{~L} \cdot \mathrm{min}^{-1}$ showed an iron concentration is $0.049 \mathrm{mg} . \mathrm{L}^{-1}$ and in membrane reverse osmosis with a feed flow rate of $14 \mathrm{~L} \cdot \mathrm{min}^{-1}$, indicating an iron concentration is $0.053 \mathrm{mg} . \mathrm{L}^{-1}$ or the percentage removal of iron content is $83.28 \%$, which is the maximum content of iron concentration is $0.3 \mathrm{mg} . \mathrm{L}^{-1}$ according to Government Regulation number 82 of 2001 . The results shows iron concentration after process can be dispose to environment safely.

\subsection{The effect of flow rate and operation time on decreasing Zinc concentration}

The results of the initial zinc analysis in rubber wastewater were $0.027 \mathrm{mg} \cdot \mathrm{L}^{-1}$. The effect of flow rate and operation time on decreasing zinc concentration is shown in Figure 4.

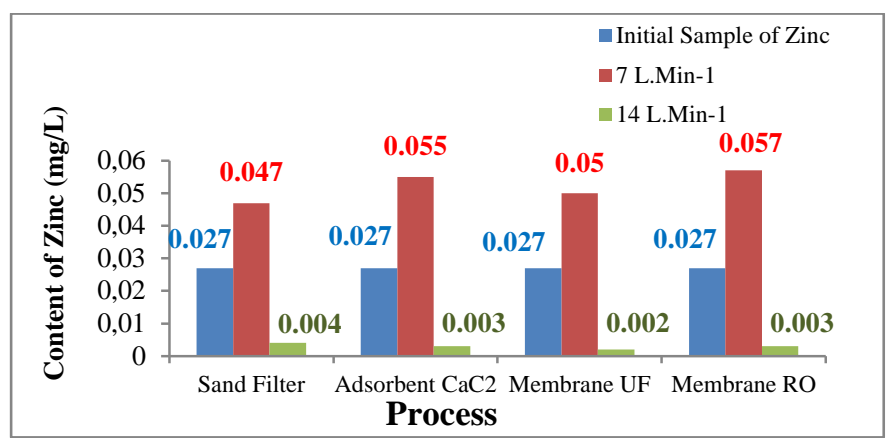

Figure 4. The effect of flow rate and operation on decreasing Zinc concentration

The results of the initial zinc analysis in rubber wastewater were $0.027 \mathrm{mg} . \mathrm{L}^{-1}$. The effect of flow rate and operation time on decreasing zinc concentration is shown in Figure 4, that the used of sand filter column showed the lowest zinc concentration is $0.004 \mathrm{mg} . \mathrm{L}^{-1}$. Continued with the use of calcium carbide residue adsorbent column showed the lowest zinc concentration is $0.003 \mathrm{mg} . \mathrm{L}^{-1}$. This indicated that the addiction of the adsorption process using calcium carbide residue resulted in greater zinc removal. Furthermore, at variation flow rate 7 and 14 L.min ${ }^{-1}$ in hybrid membrane UF - RO, shown that the feed flow rate of $14 \mathrm{~L} \cdot \mathrm{min}^{-1}$ is the optimum condition on decreasing zinc concentration. The membrane ultrafiltration with a feed flow rate of 14 L.min ${ }^{-1}$ showed an zinc concentration is $0.002 \mathrm{mg} . \mathrm{L}^{-1}$ and in membrane reverse osmosis with a feed flow rate of $14 \mathrm{~L} \cdot \mathrm{min}^{-1}$, indicating an zinc concentration is $0.003 \mathrm{mg} . \mathrm{L}^{-1}$ or the percentage removal of zinc content is $88.89 \%$, which is the maximum content of zinc concentration is $0.05 \mathrm{mg} . \mathrm{L}^{-1}$ according to Government Regulation number 82 of 2001. The results shows zinc concentration after process can be dispose to environment safely.

\section{Conclusion}

The process using sand filter, adsorbent with calcium carbide residue and hybrid membrane UF - RO, showed the results at a feed of flow rate $14 \mathrm{~L} \cdot \mathrm{min}^{-1}$ and operating time of 90 minutes had a good ability to reduce turbidity and removal heavy metal content such a iron and zinc. The results showed, that the percentage reduction of turbidity was $62.73 \%$, for percentage removal of iron and zinc concentration was $83.28 \%$ and $88.89 \%$, respectively. 
For the future study, it is important to maintenance the membrane or to replacing the re-use membrane with the new membrane to maximize the performance of membrane and to reduce pollutant content in wastewater and microorganism to prevent a biofouling in membrane.

\section{Acknowledgment}

Thanks addressed to my Supervisor, Prof. Ir. Subriyer Nasir, M.S., Ph.D. and Hermansyah, S.Si., M.Si., Ph.D. for guidance and support during this research and to Mr. Subahan, Analyst/Technician at Laboratory Separation and Purification of Chemical Engineering Universitas Sriwijaya, Inderalaya, South Sumatera, for all the laboratory support and guidance for finish this research.

\section{References}

[1] Association of Natural Rubber Producing Countries. 2010. pp. 19-20. Area. Planted during each year in ANRPC Member Countries. Vol. 1, No. 9.

[2] K. Vijayaraghavan. "Electrolytic treatment of Standard Malaysian Rubber process wastewater." Journal of Hazard Mater, 2008, vol. 150, pp. 351-356.

[3] I.O. Asia and E.E. Akporhonor. "Characterization and physicochemical treatment of wastewater from rubber processing factory." Int. J. Phys. Sci., 2007, vol. 2, pp. 61-67.

[4] H. I. Atagana. "Bacteria associated with degradation of wastes from rubber processing industry." Environ. Monit. Assess., 1999, vol. 59, pp. 145-154.

[5] A. Salahi, T. Mohammadi, A. Rahmat Pour and F. Rekabdar. "A hybrid microfiltration / ultrafiltration membrane process for treatment of oily wastewater." Desalination Water Treatment, Vol. 6 (2009), pp. 289-298.

[6] Lofrano, Giusy, Maurizio Carotenuto, dan Giovanni Libralato. 2016. Polymer functionalized nanocomposites for metals removal from water and wastewater: An overview.

[7] K. Yan and K. Zhou. "Research on the Utilization of Calcium Carbide Residue." Environmental Science Survey., 2008-S1.

[8] A. Salahi, R. Badrnezhad, M. Abbasi, T. Mohammadi, and F. Rekabdar. "Oily Wastewater Treatment Using Ultrafiltration." Desalin. Water Treat., 2012, vol. 6, pp. 289-298.

[9] S. Malekmohammadi. "Comparison of Silica, Activated Carbon, and Zeolite Adsorbents in The Removal of Ammonium, Iron, COD, Turbidity and Phosphate Pollutants, and Investigating The Effect of Discharge on The Removal of Pollutants". International Journal of Humanities and Cultural Studies, ISSN: 2356 - 5926 (2016).

[10] Wenfeng. "Adsorptive Desulfurization of Diesel Oil by Alkynyl Carbon Materials Derived From Calcium Carbide and Polyhydrocarbons." EnergyFuels, DOI:10.1021/acs.energyfuels.7b01295 (2017).
[11] X. Yang. "Inter-layer Free Cobalt-Doped Silica Membranes for Pervoration of Ammonia Solutions." Journal of Membrane Science, S0376 7388 (17), Vol. 33, pp. 417-418 (2018).

[12]Metcalf and Eddy. 1991. Wastewater Engineering. Mc Graw Hill, New York.

[13] C.W. Anderson. Turbidity 6.7. in USGS National Field Manual for The Collection of Water Quality Data, US Geological Survey, 2005.

[14] S. Rajindar. 2005. Hybrid Membrane Systems for Water Purification. Technology, System Design and Operation., Elsevier Science, vol. 1st Edition, pp. 384. 